\title{
How Can Find Similarities and Measure the Urgency of Tax Reform?
}

\author{
Abdul Rahman ${ }^{1}$ \\ \{rhnoke@gmail.com \\ Politeknik STIA LAN, Bandung, Indonesia ${ }^{1}$
}

\begin{abstract}
In general, reforms in a country conducted in according with politics and economic situations. Tax reform is an important change performed to increase the independence and developing a country in which the application differences suitable with characteristics of country. Based on the comparing tax reforms, this paper offers a model and an equation that can be used to compare tax reforms between or among countries based on the aspect of elements affecting, expectancy, and element of reform and to measure the urgency of tax reform. According to the model, the similarities of tax reform can be founded and the percentage of urgency of further tax reform can be predicted (by simulation)
\end{abstract}

Keywords: reform in taxation, flow of reform, factors affecting reform, expectancy of reform, component of reform

\section{Introduction}

As a part of the public administration reform, tax reform is a basic improvement of all tax aspects to gain a good tax system, in which equity, efficiency, and simplicity take place (Asprey et.al, 1975, Alm, 1996, Australian Government, 2015). To achieve it, tax reform requires a shift to a new paradigm by considering ideally changes in all fields of life including political, economic and social. Theoretically, improvements expected through tax reform are namely modernizing tax administration, formulating transparent and stable tax laws by involving all stakeholders, conducting law enforcement, enhancing government credibility by using tax for public interest, and having political will and commitment in formulating and implementing tax reform (Burgess and Stern, 1993).

The existence of public administration reform drives countries worldwide to conduct tax reforms. A recent World Bank report said countries are continuing to reform their tax systems, although a global economic perspective remains uncertain. In addition, the report also indicates that the number of countries involved in reform fell from 35 years ago to 31 countries. However, these countries continue to place special emphasis on reducing the burden of tax administration, for example by introducing better online systems to improve tax compliance (World Bank, 2013). The development of the tax regime in a country usually reflects the socio-economic characteristics of the country, therefore tax reform requires fundamental changes in all aspects of taxation, including, at the very least, improving the quality of human resources, tax regulation and tax information. A system to achieve an optimal tax system where simplicity, efficiency, voluntary compliance and tax revenue have increased significantly (Alm, 1996). 
In the real condition, tax reform movements in developed, developing, and transition countries are performed based on the characteristic of each country. Therefore, to get the whole picture, this study offers the model to find the similarities of tax reforms among countries in the side of driving factors of reforms, expectations toward reforms, and elements of reforms. This model also provides an equation to predict the urgency of further tax reform.

Mobile learning can overcome teacher problems regarding time management and increase student independence to understand learning material

\section{Method}

\subsection{Building a model}

The introduction of tax reforms in countries around the world during the same period suggested that there were general incentives for tax reform. The current context of globalization is a good example of this statement. On the one hand, globalization has a positive impact, especially in the aspect of trade, on the other hand, when the economic crisis breaks out in unusual and disturbing ways, its impact on public finances is felt in almost every country in the world. This condition forces the state to carry out financial reforms, including taxation. While the implementation of reforms in this sector varies according to the characteristics of each country, general factors can be considered. Based on these assumptions, a framework is systematically built to facilitate comparative analysis of tax reform, as shown below:

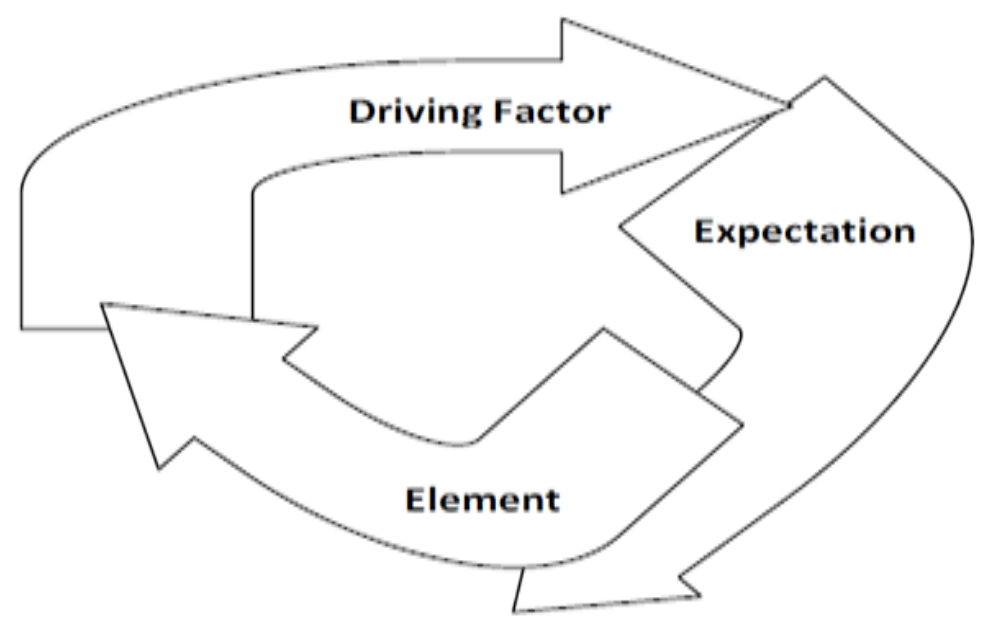

Figure 1. General framework of tax reform

This framework indicates that, in general, the journey of tax reform follows three stages. The first step is driving factors. It may be true that tax reforms are conducted because of the previous conditions influencing them. These factors then bring out expectations toward reforms as the second stage. Finally, these expectations are realized 
by many programs or elements of reforms that become driving factors for the further reforms.

Referring the general framework, then this study develops schematically a model for comparison that involves common conditions, problems faced and administrative weaknesses as aspects of the volume of driving factors, as shown in the following figure:

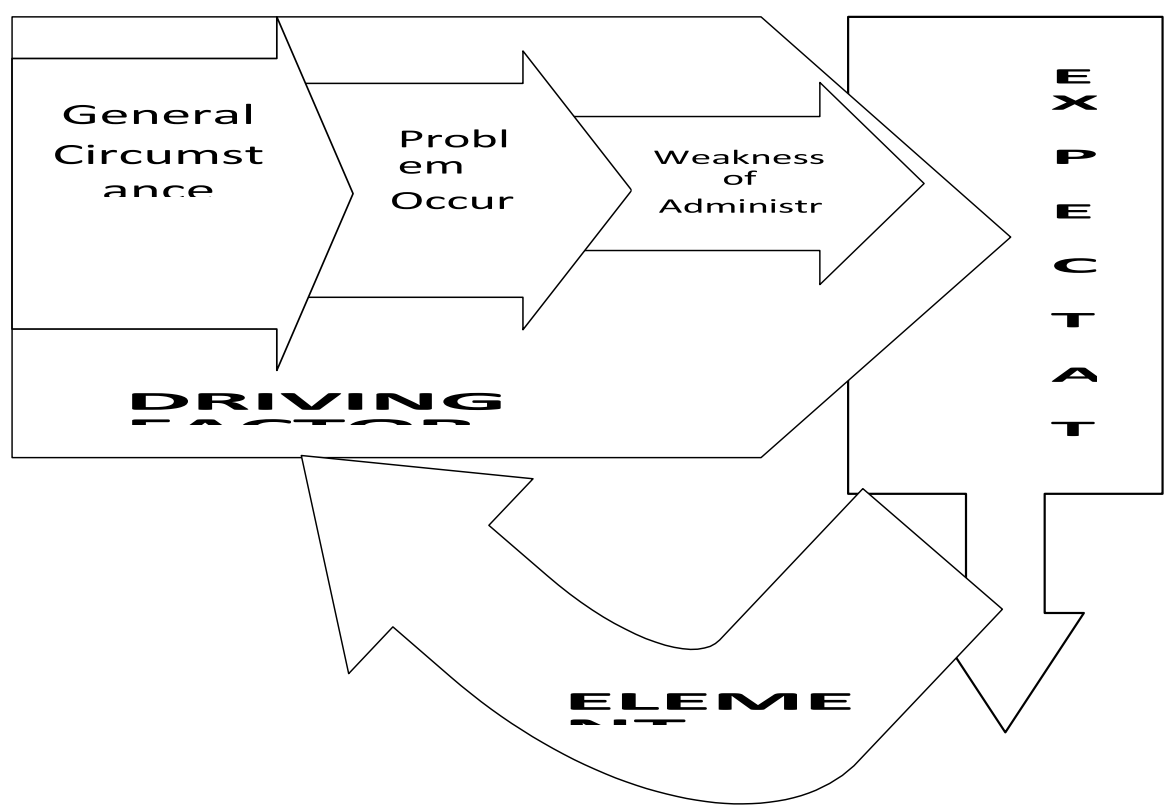

Figure 2. Model for comparison of tax reforms by driving factors, expectations, and elements

Figure 2 explores more detail figure 2, in which the existence of driving factors of tax reforms is caused by conditions of tax system in general and tax problems perceived including the weakness of administration as an important factor that affects the tax performance. By using this framework, expectedly this study can summarize all information to find out similarities of the implementation of tax reforms between countries or among countries.

Furthermore, by using this model, this study formulates an equation, namely:

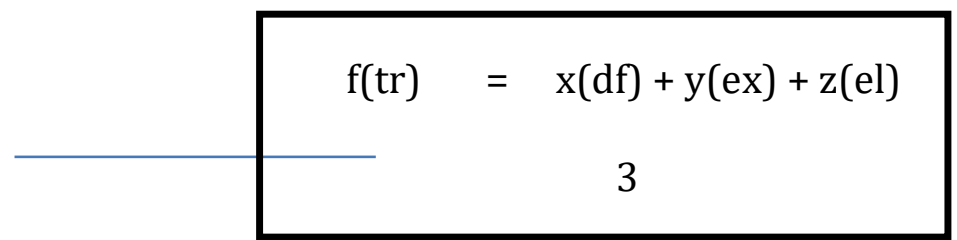

in which:

$\mathrm{f}(\mathrm{tr}) \quad=$ function of tax reform 


$$
\begin{array}{ll}
\mathrm{x}(\mathrm{df}) & =\text { driving factors } \\
\mathrm{y}(\mathrm{ex}) & =\text { expectations } \\
\mathrm{z}(\mathrm{el}) & =\text { elements }
\end{array}
$$

This equation means that the function of tax reform will run if there are factors driving the reform, expectations (goal) toward the reform, and elements (programs) to solve driving factors and to achieve expectations. By using this equation, this study can predict the urgency of the further tax reform.

Furthermore, this study built the stages of COM-ME (Comparison and Measure) by combining the model and the equation that can be elaborated as following below:

Stage 1: Using the model to compare the current tax reforms worldwide. In this stage, the result of comparison in term of similarities of driving factors become points of driving factors 1 of formula or $\mathbf{x}(\mathbf{d f}) \mathbf{1}$. Then, the similarities of expectations and elements become points of expectations 1 of formula or $\mathbf{y}(\mathbf{e x}) \mathbf{1}$ :

Stage 2: Using Strength, Weakness, Opportunity, and Threat (SWOT) Analysis to map conditions our country. According to Rangkuti (2006), the matrix that describes

\begin{tabular}{|c|c|c|c|c|c|}
\hline & & \multicolumn{2}{|c|}{ Strength } & \multicolumn{2}{|c|}{ Weakness } \\
\hline & & & Point 1 & - & Point 1 \\
\hline & & & Point 2 & - & Point 2 \\
\hline & & $\square$ & $\ldots$ & $\square$ & $\ldots$ \\
\hline \multicolumn{2}{|c|}{ Opportunity } & \multirow{4}{*}{\multicolumn{2}{|c|}{$\begin{array}{l}\text { The combination points } \\
\text { of strength and } \\
\text { opportunity become } \\
\text { points of expectations } 2 \\
\text { or } y(e x) 2\end{array}$}} & & \\
\hline- & Point 1 & & & & \\
\hline - & Point 2 & & & & \\
\hline$\square$ & ... & & & & \\
\hline \multicolumn{2}{|c|}{ Threats } & & & \multirow{4}{*}{\multicolumn{2}{|c|}{$\begin{array}{l}\text { The combination points of } \\
\text { weakness and threats } \\
\text { become points of driving } \\
\text { factors } 2 \text { or } x(\mathrm{df}) 2\end{array}$}} \\
\hline- & Point 1 & & & & \\
\hline- & Point 2 & & & & \\
\hline & & & & & \\
\hline
\end{tabular}
systematically the analysis is as follows:

Table 1. Matrix Strength, Weakness, Opportunity, and Threat (SWOT) Analysis

The combination points of weakness and threats become points of driving factors 2 of formula or $\mathrm{x}(\mathrm{df}) 2$, and then the combination points of strength and opportunity become points of expectation 2 of formula or y(ex)2.

Stage 3: Based on the using model and SWOT analysis, the study then formulates potential elements appropriate with characteristics and economy conditions of our country. Points resulted become points of elements of formula or $\mathrm{z}(\mathrm{el})$.

Stage 4: Determining the formula to predict the urgency of further tax reform as illustrated below: 


$$
f(\operatorname{tr})=\quad[x(d f) 1+x(d f) 2]+[y(e x) 1+y(e x) 2]+z(e l)
$$

3

The result of formula is first to be identified as 100 percent. It means the value of urgency of further tax reform proposed to government is started in 100 percent. The urgency in percentage is to be reduced if there are improvements from the government.

\subsection{Implementation of model}

To apply this model, this study researched documents on the application of tax reform in transition countries, developed countries, and developing countries. The countries with a gap follow the IMF classification, in which the countries of the world are divided into developing countries ${ }^{5}$, then developed countries ${ }^{6}$ and countries with economies in transition ${ }^{7}$ (Martinez, et. Al, 1997). In addition, in their development, all countries of the world are divided by income per capita, namely (1) countries with a lowincome level with a per capita income of no more than USD 975, (2) countries with a lower middle-income level with a per capita income population from USD 976 to USD 3855 , (3)) middle and high-income countries by per capita income from USD 3856 to USD 11905, and (4) high income countries by per capita income more than 11,906 dollars. The World Bank classifies all low-and middle-income countries as developing countries (World Bank, 2010).

The literature review is carried out by using Scopus, web of science, and Google scholar databases. This study finds 40 articles in the period of 1987 until 2014 by keywords of public administration, tax administration, and tax reform either transition, developed, or developing countries that contain information about driving factors, expectation, and elements of reforms. The study looked at this period because the tax reforms in the large scale have conducted since 1983..

\section{Result and Discussions}

This study presents the result based on the Stages of COM-ME that can be elaborated as follow:

\section{Result of Stage 1}

Data from the study of documents are analyzed and be highlighted by following the framework of comparison. The findings are then presented in each group of countries based on driving factors, expectations, and elements of reforms to facilitate in seeking the similarities among countries associated with tax reform in the global context, as shown below:

\section{Driving factors}

The results from the driving factor aspect for each category of countries: 


\section{Transition countries}

\section{Common conditions}

The introduction of taxation in transition countries follows the model of a centralized economy in which the role of the state in controlling the economy plays an important role. Taxes are becoming the main government instrument for economic development, with corporate income tax, sales tax and payroll tax being the main types of taxes. The government is focused on collecting taxes from state-owned companies and a small individual income tax that does not have much corporate dominance and taxes on the private sector and property. Therefore, it is not surprising that almost $50 \%$ of the income is used to subsidize state-owned companies and households and that the corporate tax in this case in Western countries is more than four times higher than them.

\section{Problem occurred}

Prior to tax reform, transitional economies had problems with low voluntary compliance due to a lack of public trust in the government, which was prone to corruption, and a lack of public awareness of the need to pay taxes, which continues to be a burden. Low compliance results in high rates of tax fraud and tax arrears. This condition is exacerbated by the absence of tax audits that do not use modern audit methods and a lack of law enforcement. Uncertain and unstable tax systems emerged simultaneously due to excessive government influence due to the dualism of owner and operator duties, fluctuating tax rates, and a lack of coding and database systems. This condition led to low tax revenues and a financial crisis.

\section{Weakness of tax administration}

In area of tax administration, transitional economies face challenges related to computerized information systems for tax filing and collection, including weak tax audit technical standards for corporate standards and accounting that are incompatible with modern accounting standards. Bad opportunities for tax officers due to lack of training and low salaries lead to dishonest civil servants' behavior, including poor service to taxpayers. 


\section{Developed countries}

\section{General conditions}

The introduction of taxation in developed countries has a fundamentally strong democratic tradition in which taxpayers are fully viewed as a society with equal rights and responsibilities and public participation in political decisions aimed at solving problems, including tax ones. The public also knows what taxpayer dollars can be spent on. The tax system is run by strict law enforcement agencies, no tax evasion, customer focus, efficiency and supervised regulation. In these circumstances, it is generally accepted that voluntary compliance is high with income tax as the largest tax revenue, accounting for about $36 \%$ or about two-thirds of tax revenue and about $31.2 \%$ of GDP. The use of state revenues for public purposes is also quite large: state funding for social security and health care exceeds $31 \%$.

\section{Problems}

High levels of corruption in developed countries have led to a decline in public confidence in government. This condition was aggravated by the global economic crisis, which led to the state's financial crisis. This situation has resulted in lower tax sentiment and high rates of tax evasion, tax evasion and incomplete reporting. In addition, high tax rates and tax compliance costs caused by law enforcement are other factors that cause taxpayer noncompliance.

\section{Tax administration}

The high dependence of the tax administration on computer technology leads to a lack of relations between taxpayers and tax officials. The lack of honesty of the tax administrator is supported by the constant high influence of political power on the implementation of tax administration. 


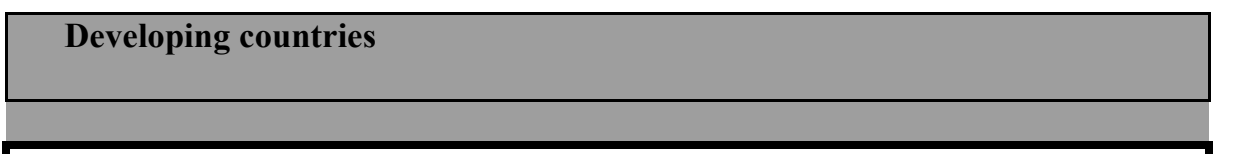

\section{General circumstances}

The tax role towards state revenue is extremely large due to the high demand of country after independence from colonialism, financing war and reconstruction, public necessity for development, and government operations for the public service. Surprisingly, one of the first things to note is that almost $80 \%$ of state revenues depend on tax revenue. This dependence is also supported by lack of involvement of non-tax revenue sector. In term of tax type, it is noted that two thirds of tax revenue come from indirect taxes such as foreign trade taxes and customs. The existence of country's dependence on foreign loans leads to the quite large role and influence of international organizations and some developed countries in decisions relating to fiscal and economic.

\section{Problem perceived}

It is interesting to see that problems in developing countries occur because of the complex tax system, narrow tax base, high tax compliance cost, injustice such as loopholes and exceptions, and high government intervention. The existence of state finance deficit due to the high debt, inflation, banking crisis and global economic crisis leads an impartial tax policy such as high tax rates and complex administrative procedures. Furthermore, the economic inequality, lack of tax education and knowledge, large tax burden, and inequity service led to the high rate of non- compliance such as tax evasion and tax avoidance. In addition, the lack of integrity due to poor salary structure and law enforcement brings to moral hazard behaviors that tend to corrupt.

\section{Weakness of tax administration}

The weak infrastructure of tax administration leads to the fact that tax administration services are not maximized. Tax administration implementation tends to be unstable and ineffective due to the high cost of tax administration. The low role of personal income tax is due to the fact that the tax administration system is not yet supported, while the government remains focused on enforcing tariffs and improving tax legislation. 


\section{Expectations and elements of tax reforms}

From the expectation and component of reform aspect, this study resulted:

\section{Transition countries}

\section{Expectancy}

At the government level, it is noticeable that the transition countries are expecting an improvement and modernization of the tax administration and are gradually starting to introduce Western accounting systems for the application of taxes. In addition, oversee tax collection and improve VAT compliance by integrating VAT administration and corporate tax. The increase in tax revenue is expected through four main taxes, namely consumption tax, wage tax, profit tax and duty, which then strengthen the tax reduction mechanism, use tax taxes as the basis for the introduction of unmeasured and monitored taxes, create limits on non-taxable income and reduce income volatility, by not depending on a source of income. With regard to taxpayers, tax reform is expected to strengthen the implementation of self-assessment, capacity and independence of administrators so that services to taxpayers are maximized and there is a close relationship between tax administrators and taxpayers in the context of customer satisfaction.

\section{Components of reform}

In order to realize these expectations, the elements of the tax reform carried out in the transition economies mainly consist in the development of a tax system that introduces a modern administrative system in Western and European countries by adding the right IT system to regulate tax collection, reduce export and import taxes. to increase the proceeds are used. On the commercial side, establishing tax breaks for pensions, grants, social security insurance reimbursements, expanding the tax base, introducing new taxes, final taxes, and changing tax rates to increase tax revenue. 


\section{Developed countries}

\section{Hopefulness}

It is widely recognized by the government that the expectations of developed countries are to increase tax revenues to weather the economic crisis, improve tax compliance, and raise taxpayers' morale to avoid tax behavior such as tax evasion and tax evasion. In addition, the government hopes that the honesty of administrators will be increased to prevent corruption. From the taxpayer's point of view, there is particular hope for fair regulation and enforcement, particularly in relation to the private sector. It is also expected that services to taxpayers will increase through modern tax administration without disrupting human relationships.

\section{Element of reform}

To meet these expectations, industrialized countries are implementing various elements of tax reform, in which the definition of taxation is based on a market economy and tax services based on customer satisfaction with one service, and organizations are built depending on their functions. As a result, the modernization of the tax administration continued with the development of information technology to combat fraud. Subsequently, the government passed a number of decrees that enhance the role of VAT on goods and services, including simplifying the structure of the income tax by standardizing tax rates and expanding the tax base. In addition, the role of the tax system has been strengthened by simplifying tax laws, providing taxpayers with tax education and information, reducing tax amnesty, and tax audit programs based on a risk pyramid approach to tax segmentation. The Tax Integrity and Good Governance program is also conducted to build trust between government and taxpayers, including strengthening social norms. 


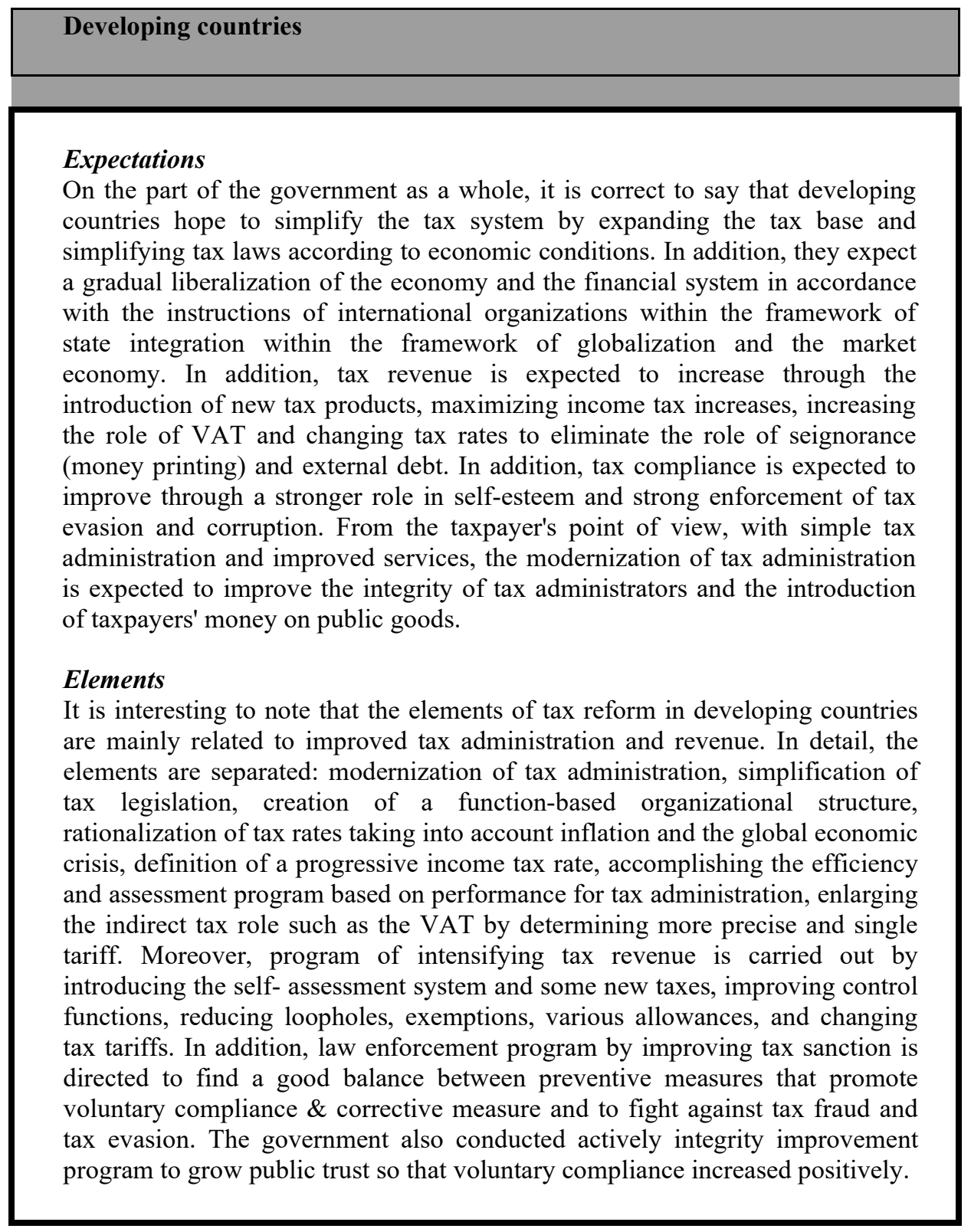

Tax reform is, in fact, the price that the countries of the world must pay by taxing the population in order to achieve improvements in any sector and achieve an optimal tax system in a comprehensive manner. The globalization framework is likely to allow several countries to carry out tax reforms simultaneously, taking into account the same factors. The results of documentary studies using comparative flows show similarities in tax reform implementation in terms of driving forces, expectations and 
elements in transitional, industrialized and developing countries.

As for the driving forces behind the reforms, they agreed that the economic crisis, financial crisis and high inflation were empirically the main driving forces. In this context, it is not surprising that taxation is one of the main sources of government revenue. Despite political instability, a complex and unstable tax system, weak enforcement and volatile tax rates. Ineffective tax administration, poor integrity and incompetence of tax administrators, and poor professional relations between taxpayers and tax administrators, including non-tax behavior such as tax evasion, tax evasion and tax corruption, are expected to increase tax revenues. essential. by using a simple tax system in regulatory and tax administration processes that improves morale and integrity of tax officials and reduces violations. To achieve this, various innovations or elements have been introduced through the development of information technology-based tax infrastructure, the introduction of new taxes such as VAT and sales tax, and changes in tax rates. In addition, the tax reform implemented the simplification of tax laws and regulations separately, improved the income tax system, imposed harsh and severe penalties for non-compliance, implemented programs to improve integrity and morality, controlled tax collection through an audit process, and integrated direct and indirect taxes. Reducing exemptions, incentives and loopholes that can lead to violations, and improving services for taxpayers as participants in the tax system.

According to these results, then this study summarized them, in which the similarities of driving factors become points of driving factors 1 of formula or $\mathrm{x}(\mathrm{df}) 1$ and the similarities of expectations and elements become points of expectations 1 of formula or $y(e x) 1$. As simulation, after more discussions for instances, the study determined the same driving factors of study as $\mathrm{x}(\mathrm{df}) 1$ with 10 points and the expectations and elements of study as $y(e x) 1$ by 20 points. Afterward, this study continued the process with stage 2 .

\section{Result of Stage 2}

This study uses SWOT analysis to map conditions of our country to obtain $\mathrm{x}(\mathrm{df} 2)$ and $y(e x) 2$, as shown in the following table:

Table 2 Matrix Strength, Weakness, Opportunity, and Threat (SWOT) Analysis

\begin{tabular}{|c|c|c|}
\hline 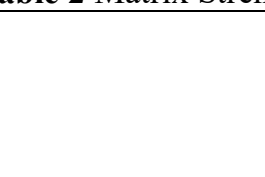 & $\begin{array}{ll} & \text { Strength } \\
- & \text { Point } 1 \\
- & \text { Point } 2 \\
\square & \ldots\end{array}$ & $\begin{array}{ll} & \text { Weakness } \\
- & \text { Point } 1 \\
- & \text { Point } 2 \\
\square & \ldots\end{array}$ \\
\hline $\begin{array}{ll} & \text { Opportunity } \\
- & \text { Point } 1 \\
- & \text { Point } 2 \\
\square & \ldots\end{array}$ & $\begin{array}{l}\text { As simulation, this study } \\
\text { determines that points of } \\
\text { strength + points of } \\
\text { opportunity are } 10 \text { points } \\
\text { for } y(e x) 2\end{array}$ & \\
\hline $\begin{array}{ll} & \text { Threats } \\
- & \text { Point } 1 \\
- & \text { Point } 2 \\
\square & \ldots\end{array}$ & & $\begin{array}{l}\text { As simulation, this study } \\
\text { determines that points of } \\
\text { strength }+ \text { points of } \\
\text { opportunity are } 10 \text { points for } \\
x(d f) 2\end{array}$ \\
\hline
\end{tabular}

According to this table, the study obtains that the combination of weakness and threat 
points are 10 points or $\mathbf{x}(\mathbf{d f}) 2=\mathbf{1 0}$ points and the combination of strength and opportunity points are 10 points or $\mathbf{x}(\mathbf{d f}) 2=\mathbf{1 0}$ points.

\section{Result of Stage 3}

This study obtains the driving factors $[x(d f) 1+x(d f) 2]$ and expectations[y(ex $) 1+y(e x) 2]$ for further tax reform. Based on result of stage 1 and stage 2, then the study formulates potential elements appropriate with characteristics and economy conditions of our country. As simulation, the study determines the number of elements is 20 or $\mathbf{z}(\mathbf{e l})=\mathbf{2 0}$ points.

\section{Result of Stage 4}

This study inputs data to the formula, as shown below:

$$
\begin{aligned}
& {[x(d f) 1+x(d f) 2]+[y(e x) 1+y(e x) 2]+} \\
& z(e l)
\end{aligned}
$$

Referring the formula $\mathrm{f}(\mathrm{tr})=$ in which

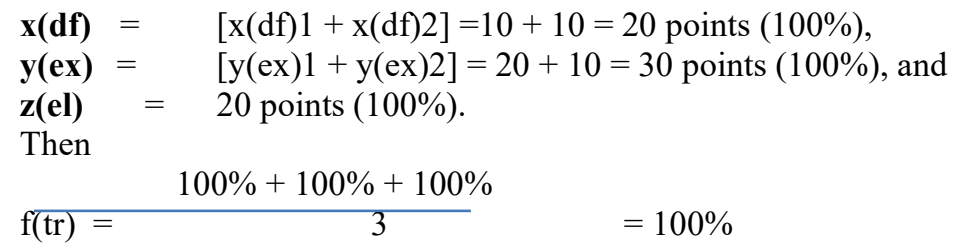

It means the urgency of further tax reform of $\mathbf{f}(\mathbf{t r})$ is $\mathbf{1 0 0}$ percent. This is a maximal point of urgency of the further tax reform that this study proposed to the government based on the result of similarities of tax reform worldwide and the current conditions of tax system in the country.

If, in the journey, the government makes changes because of many considerations, in which points of $\mathbf{y}(\mathbf{e x})$ become 15 points from 30 points and points of $\mathbf{z}(\mathbf{e l})$ become 10 points of 20 points as showed in the following equations:

$\mathbf{x}(\mathbf{d f})=[\mathrm{x}(\mathrm{df}) 1+\mathrm{x}(\mathrm{df}) 2]=20$ point $(100 \%)$

$\mathbf{y}(\mathbf{e x})=[\mathrm{y}(\mathrm{ex}) 1+\mathrm{y}(\mathrm{ex}) 2]=15(50 \%)$, and

$\mathbf{z}(\mathbf{e l})=10$ points $(50 \%)$

And then, the calculation becomes:

$$
\mathrm{f}(\mathrm{tr})=\quad-100 \%+50 \%+50 \%=66.67 \% 3
$$

By this result, the study can assume that the urgency of further tax reform in the side of government is around $66 \%$. 


\section{Conclusion}

This model proves that there is sameness of tax reforms worldwide in the aspect of elements affecting of reforms (elaborated with general circumstances, problems perceived, and weakness of tax administration), expectations toward reforms, and elements or programs of reforms. It can be concluded that this model can be used and facilitate in finding the similarities of tax reforms between countries or among countries. The results obtained can be used to create a tax reform plan in the future appropriate with characteristics and conditions of a country.

Following the COM-ME Stages (comparison and measure stages), this study can determine an equation to measure the urgency of further tax reforms. The result started with the point assumption of 100 percent as a maximal urgency for further tax reform. The percent of urgency will change if there are modifications from the government or stakeholder.

\section{References}

[1] Aberbach, Joel D., and Tom Christensen."The Challenges of Modernizing Tax Administration Putting Customers First in Coercive Public Organizations." Public policy and administration 22.2 (2007): 155-182.

[2] Alm, James, and Benno Torgler. "Culture differences and tax morale in the United States and in Europe." Journal of economic psychology 27.2 (2006): 224-246.

[3] Alm, James. "What is an "optimal" tax system." National Tax Journal 49.1 (1996): $117-133$.

[4] Asher, Mukul G., and A. S. Level. "Design of tax systems and corruption." Conference on Fighting Corruption: Common Challenges and Shared Experiences, Singapore: Konrad Adenauer Stiftung and the Institute of International Affairs. 2001.

[5] Besfamille, Martin, and Cecilia ParlatoreSiritto."Modernization of tax administrations and optimal fiscal policies." Journal of Public Economic Theory 11.6 (2009): 897-926.

[6] Bhatnagar, Subash. "Modernizing tax administration in Singapore." Washington, DC World Bank (2000).

[7] Bird, Richard M. "Administrative dimensions of tax reform."University of Toronto. Toronto, Canada. Processed (2003).

[8] Bird, Richard M. "Managing Tax Reform." Bulletin for International Fiscal Documentation 58.2 (2004): 42-55.

[10] Bird, Richard M. Administrative Dimensions of Tax Reform. Asia-Pacific Tax Bulletin, (2004): 134-150.

[11] Bird, Richard. "Tax challenges facing developing countries." Institute for International Business Working Paper 9 (2008).

[12] Blijswijk, Jacques AM, et al. "Beyond ethical codes: The management of integrity in the Netherlands tax and customs administration." Public Administration Review 64.6 (2004): 718-727.

[13] Box, Richard C. "Running Government Like a Business Implications for Public Administration Theory and Practice." The American Review of Public Administration 29.1 (1999): 19-43.

[14] Burgess, Robin, and Nicholas Stern."Taxation and development." Journal of economic literature 31.2 (1993): 762-830. 